\title{
Marshall's Voice
}

\author{
Thomas Halper* \\ Baruch College \& CUNY Graduate Center
}

\begin{abstract}
Most judicial opinions, for a variety of reasons, do not speak with the voice of identifiable judges, but an analysis of several of John Marshall's best known opinions reveals a distinctive voice, with its characteristic language and style of argumentation. The power of this voice helps to account for the influence of his views.
\end{abstract}

\section{CONTENTS}

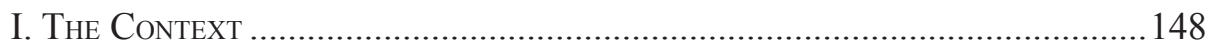

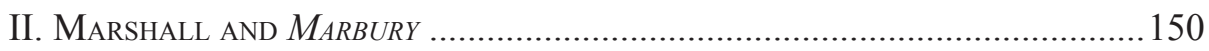

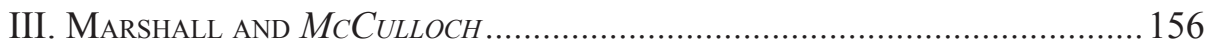

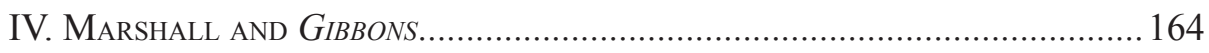

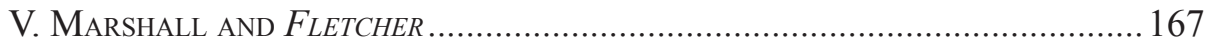

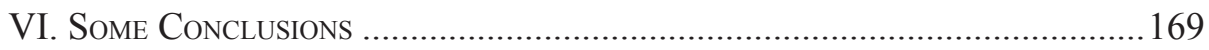

In most of what we read, the individuality of the writer has been scrubbed off, as if by cosmic steel wool, and we are left with paragraphs seemingly without parents. Who writes Medicare instructions or announcements of academic meetings or credit card commercials? We never know nor are we ever interested in knowing. Much of judicial writing, it must be acknowledged, also seems to have been written by no one in particular. Perhaps, this is because it was produced by clerks steeped in anonymity. Perhaps, this is because the opinion was a committee product, in which the original draft was pelted with so many additions and deletions that the entire document had to be cloaked in featureless prose in order to hide its mixed parentage. Or perhaps the judge deliberately sought to write an opinion from nowhere.

This is not what we find with John Marshall. As surely as with Charles Dickens, David Foster Wallace, or Elmore Leonard, Marshall's prose speaks to us with an identifiable voice. Whether it reflects the Virginia frontier of his childhood, literary and historical classics he mastered on his own, or his distinct persona and whether it was deliberately concocted or emerged naturally, the Marshall voice is unmistakable. This essay represents an attempt to understand and explore the nature of that voice.

* Thomas.Halper@baruch.cuny.edu. I am grateful to Benedetto Fontana, who read an earlier version of this paper and offered numerous insightful suggestions. 


\section{The CONTEXT}

Why have judicial opinions? One obvious answer is to help legitimize the Court and its work by providing rational justifications for its decisions. Courts, as Hamilton reminds us, ${ }^{1}$ lack the powers of the purse or the sword, instead possessing "merely judgment"; if this judgment is to be made visible, it must be publicly expressed, as in opinions. A second is to facilitate the use of precedent, which is thought to make for consistency, efficiency and fairness. An opinion in one case will make it very much easier to decide if the case is applicable in another. But not every opinion will further these goals. If it is unclear, ambiguous or indecisive, if it appears biased, poorly reasoned or indifferent to pressing circumstances, if it radically confounds expectations, ignores history and practice or ends in unworkable instructions - if these defects blight the opinion, it can hardly be successful. Marshall, preeminently a practical man, needed no reminder of this. But how would his opinions read? If opinions represent the law and the law is impersonal, would his opinions be impersonal, too, produced as if written by a platonic archetypical judge? Or, on the theory that "there are no voiceless words," would his opinions sound with the voice of Marshall?

But what is voice? Literally, it refers to the sound, rhythm, timbre, and intonation of a speaker, and it is sufficiently identifiable on an individual basis to accommodate voice recognition software. But when used metaphorically, voice seems to recall Augustine's famous riposte on time. ${ }^{3}$ At its heart, though, it means at least this: voice reflects the personal presence of the writer, and it is a social act in that it presumes an audience. A writer with a distinctive voice may be said to be there, in the room with the reader.

To begin, it is Marshall's voice that we are discussing. The clerks who today research and virtually ghost write many judicial opinions were unknown in his day. What we read is what Marshall wrote. At the same time, however, if it was his voice, it was not entirely under his sole control but was forced to follow certain long accepted conventions. He well understood, for example, that opinions are exercises in justification and persuasion. The author does not relate how he came to decide as he did - were childhood experiences determinative or perhaps his daughter passed on an anecdote that focused his mind? Instead, venerable established unspoken rules compel the judge to defend his conclusion on the basis of evidence and reason, and to do so in the form of an argument. And he must, too, take into account his audience, most proximately, his fellow justices. As Justice Ginsburg observed, "In writing for the Court, one must be sensitive to the sensibilities and mindsets of one's colleagues, which may mean avoiding certain arguments and authorities, even certain words." And the audience also includes the larger legal community,

1 Alexander Hamilton, James Madison, \& John Jay, The Federalist Papers (Clinton Rossiter ed. 1961).

2 Mikhail Bakhtin, Speech Genres and Other Late Essays 124 (Caryl Emerson \& Michael Holquist eds., Vern McGee trans., 1986).

3 "If no one asks me, I know what it is. If I wish to explain it to him who asks, I do not know." Confessions 162 (Albert C. Outler ed. \& trans., n.d.).

4 Ruth Bader Ginsburg, Speaking in a Judicial Voice, 67 N.Y.U. L. Rev. 1185, 1194 (1992). 
the media, perhaps even the general public. If his persuasion is to succeed even partially, it must be targeted appropriately at these audiences, maybe flattering them with pointed references or adopting their perspective or, at the very least, addressing their concerns. Yet if a justice operates within limits, so do nearly all other writers. When they disdain and reject these limits - like, say, Joyce in Finnegan's Wake they run the risk of losing much of their audience.

Marshall's is also a voice that is time bound to the early nineteenth century. It naturally reflects the values and attitudes of the day and the generally accepted style of judicial writing that prevailed at the time. ${ }^{5}$ It also had to make do with a technology that by today's standards is primitive, indeed. There was no Internet or LexisNexis to help with research, for example, nor even a Court library. Nor could Justices draw on copious written briefs from the litigants or scan dozens of law reviews critiquing and interpreting opinions. Moreover, prior to Marshall's appointment, the Court's opinions were usually given orally, with the unofficial reporters, Alexander Dallas and William Cranch, compiling the opinions from the justices' notes, sometimes taking liberty with the language. The cases' utility as precedents, therefore, was always somewhat problematic. Also, obviously, in a new republic, today's vast backlog of precedents that typically constitute the heart of opinions ${ }^{6}$ was simply nonexistent.

Perhaps most obviously, Marshall's voice, like all voices, was intertextual, ${ }^{7}$ in that it revoices words and phrases and utterances from earlier writers. He did not create his own language, but rather used what others had created, reinforcing this, altering that, and in this way entering into a kind of dialogue with them. ${ }^{8}$ Thus was Marshall, in a discretionary and unmechanical way, intertexting with the opinions and arguments of his own day plus the commentaries of Blackstone plus the essays we know as the Federalist plus much more - and all this rooted him deeply in his time and place.

Marshall brought considerable credibility to his efforts. Unpretentious and with simple tastes, he first "gained national fame" when, as a diplomat sent to France, he denounced an attempt at bribery. Earlier, he had been a combat veteran during the War for Independence, a leader of the Virginia appellate bar, and a legislator at the state and national level who participated in the ratification of the Constitution. Later, President Adams named him Secretary of State. Perhaps equally important as this impressive resume, Marshall was also immensely likable; apart from Jefferson, even his adversaries thought well of him. Much of the leadership he exercised was accomplished in unassuming ways - for example, discussing cases over a few glasses of Madiera - and so effective was he that Jefferson conceded, "It will be difficult to find a character of firmness enough to preserve his independence on

In contrast, Justice Kagan's voice is “remarkably conversational.” Laura Krugman Ray, Doctrinal Conversation: Justice Kagan's Supreme Court Opinions, 89 InD. L.J. Supp. 1, 2 (2013).

6 Jack Knight \& Lee Epstein, The Norm of Stare Decisis, 40 Am. J. Pol. Scr. 1018 (1996).

7 George Kamberelis \& Karla Danette Scott, Other People's Voices: The Coarticulation of Texts and Subjectivities, 4 Linguistics \& Educ. 359 (1992).

8 Mikhail Bakhtin, The Dialogic Imagination: Four Essays (Michael Holquist ed., Caryl Emerson \& Michael Holquist trans., 1992).

9 Timothy S. Huebner, Lawyer, Litigant, Leader: John Marshall and His Papers, 48 Ам. J. Leg. Hist. 314, 317 (2006). 
the same bench with Marshall." ${ }^{10}$ His frontier persona may have induced some to underestimate his intelligence, political savvy, and work ethic, but in the end, this operated to his advantage. Aristotle says that the persuasive speaker should possess practical intelligence, a virtuous character, and good will. ${ }^{11}$ Marshall did not assert that he possessed these qualities, for that would have been counter productive and hostile to his deepest instincts, but in his conduct he seemed to exemplify them. In his opinions, too, he repeatedly emphasized workability, spoke with a certitude that conveyed trustworthiness, and relied on logical chains of reasoning.

This essay will examine Marshall's voice in the context of four of his most famous opinions, Marbury v. Madison (1803), ${ }^{12}$ McCulloch v. Maryland (1819), ${ }^{13}$ Gibbons v. Ogden (1824), ${ }^{14}$ and Fletcher v. Peck (1810). ${ }^{15}$

\section{Marshall AND MARBURY}

Consider, first, Marbury v. Madison, his renowned opinion establishing the right of the Supreme Court to review the constitutionality of acts of Congress. William Marbury, a financier who had "elbowed his way to wealth and power [and] moved easily into the highest circles of the Federalist elite," sought the position of justice of the peace in Washington, D.C., "the most powerful public office in the lives of the common people." 16 Defeated by Jefferson in the 1800 election, the Federalist President Adams appointed Marbury to the position two days before Jefferson took office, and the Federalist Senate confirmed the appointment on the next and final day, but in the rush the commission necessary for Marbury to serve was not delivered. Jefferson instructed his Secretary of State, James Madison, to refuse to deliver the commissions and made his own appointments. Marbury maintained that delivering the commission was only a formality; Madison had no discretion in the matter; he had to provide the commission. But he refused.

What to do? Marbury, relying on section thirteen of the Judiciary Act of 1789 ("the Supreme Court ... shall have power to issue .... writs of mandamus, in cases warranted by the principles and usages of law") ${ }^{17}$ went directly to the Supreme Court, seeking a writ of mandamus to compel Madison to hand over the commission.

Speaking for a unanimous Court, Marshall declared Marbury entitled to his commission, pillorying Madison for not doing his duty. He demonstrates that the power to appoint is distinct from the duty to deliver the commission. ${ }^{18} \mathrm{He}$ faults the Secretary of State for his failure to "obey the laws"19 and for violating "a vested

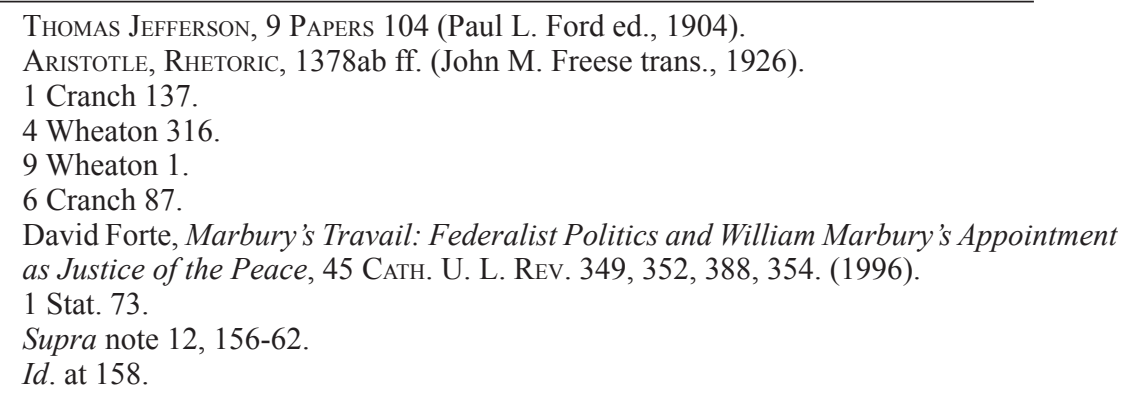


legal right. ${ }^{20} \mathrm{He}$ conjures up hypotheticals to illustrate the Secretary's obligation, ${ }^{21}$ and in a flourish announces that the government "will certainly cease to deserve the high appellation [of a government of laws, and not of men] if the laws furnish no remedy for the violation of a vested legal right." 22 He then goes on for two additional pages to establish the obvious fact that Marbury was injured, ${ }^{23}$ and for another three pages to remind us that delivering the commission is a ministerial duty and not discretionary. ${ }^{24}$

Only after nineteen pages does Marshall consider the jurisdictional question, which normally is addressed first. At this point, he announces that the question was not whether Marbury was entitled to his commission, but instead whether he could seek a writ of mandamus from the Supreme Court. Article III, the brief and cryptic portion of the Constitution bearing on courts, reads in part: "In all cases affecting ambassadors, other public ministers and consuls, and those in which a state shall be a party, the Supreme Court shall have original jurisdiction." ${ }^{25}$ It did not mention writs of mandamus, but the government contended that the brief list was a floor to which Congress could add. Marshall, evidently relying on expressio unius est exclusio alterius, reasoned that what was not listed was excluded. Thus, as written, Article III would not permit Marbury to seek the writ from the Court. The nineteen earlier pages supporting Marbury's claim were of no effect.

Though his classic biographer calls the idea "absolutely new," "daring," and "novel," 26 Marshall was not an original thinker, and his opinion here tracks Hamilton's views in Federalist $78 .{ }^{27}$ The Constitution must be superior to ordinary laws, he argued, or else deputy would be superior to principal and servant to master; and it must be left to the courts to make the determination. But if Marshall takes Hamilton's argument, he presents it in his own way. As he often did, he implicitly poses seemingly innocuous questions that, once they yield their obvious answers, clang shut, closing the trap. Thus did Jefferson, his old foe, write Marshall's colleague, Joseph Story, "When conversing with Marshall, I never admit anything. So sure as you admit any position to be good, no matter how remote from the conclusion he seeks to establish, you are gone. .. . Why, if he were to ask me if it were daylight or not, I'd reply, 'Sir, I don't know, I can't tell.'”28

Thus, we can imagine Marshall asking a pair of questions. Is this a constitution we are discussing? Yes, of course, we reply. That is what the document is called. Well, then, is a constitution different from a statute? Yes, it must be, for it may be defined as "a superior law, unchangeable by ordinary means." If superior, must it not prevail over a conflicting statute? Yes, for that is what "superior" means. Otherwise, constitutions would be "absurd attempts, on the part of the people, to limit a power in its own nature illimitable." ${ }^{29}$

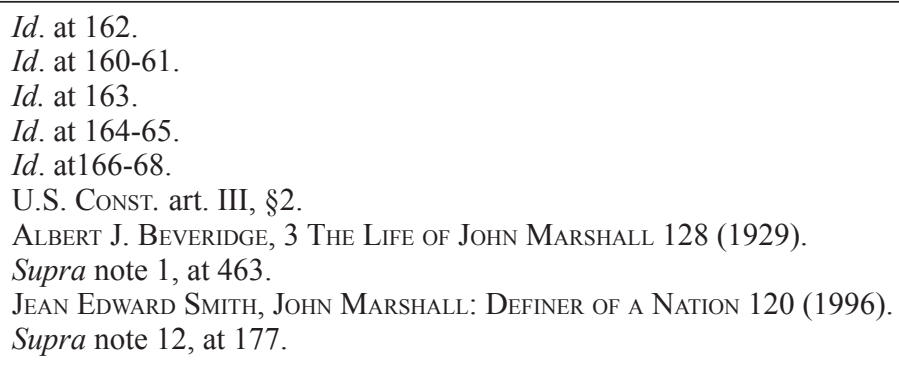


Marshall's second question is: is this a court? Why, yes, that is what it is called. What, then, is the first and irreducible function of courts? To decide disputes, we answer weakly. No, he replies, "It is emphatically the province and duty of the judicial department to say what the law is." ${ }^{30}$ Only by saying what the law is can courts proceed either to decide disputes or, as in this case, to decide that they cannot decide. If it is the duty of courts to say what the law is, it must be their duty "if two laws conflict with each other [to] decide on the operation of each." 31 That is, to identify those occasions where Constitution and statute conflict, and to declare the statute invalid. The Constitution is a law, and the Court is duty bound to follow it. ${ }^{32}$ The argument is all wrapped up as neatly as a Christmas present. Indeed, it takes on an aura of inevitability that induces us to forget four very pertinent considerations that Marshall overlooked.

First, the facts of the Marbury case seem so clear-cut that Marshall feels able to argue that the Court was really not exercising discretion, but merely pointing out what anyone could see. But suppose the conflict is not obvious - and presumably the obvious conflicts are conflicts Congress would be most likely to notice and avoid, and thus be quite rare. What then? In those cases where the law/Constitution conflict is debatable, would the Court be seen to be exercising discretion? If so, it would be harder to argue in these numerous cases that the conflict was between the Constitution and a statute than between the Court and Congress. Should judicial review, then, be confined to rare, clear-cut cases?

It is this point that advocates of judicial self restraint have repeatedly emphasized, and it is central because it is tied to the famous counter-majoritarian difficulty. ${ }^{33}$ If a legislature makes what Thayer called a "clear mistake" 34 in adopting a law that is plainly unconstitutional - as in Marbury - a court's declaring it invalid may raise few difficulties. If clearly unconstitutional laws survive, why have a Constitution? "To what purpose are powers limited, and to what purpose is that limitation committed to writing, if these limits may at any time be passed by those intended to be restrained?" 35 The clarity of the conflict confirms Marshall's assumption that judicial discretion is minimal. But if a court declares a law invalid in the absence of a clear mistake, it is exercising considerable discretion - the verdict by definition is contested - and placing its judgment above the legislature's. Yet as the legislature is elected and the judges are appointed effectively for life, their decision takes on an anti-democratic caste. Marshall avoids the problem by not raising it, but as there will be very few clear mistakes, a robust judicial review will confront this issue repeatedly.

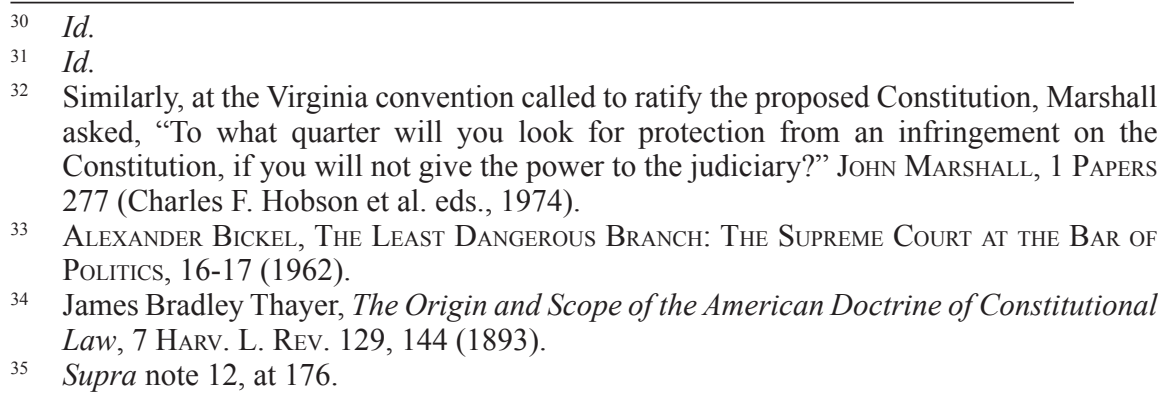
asked, "To what quarter will you look for protection from an infringement on the Constitution, if you will not give the power to the judiciary?" John Marshall, 1 Papers 277 (Charles F. Hobson et al. eds., 1974).

33 Alexander Bickel, The Least Dangerous Branch: The Supreme Court at the Bar of Politics, 16-17 (1962).

34 James Bradley Thayer, The Origin and Scope of the American Doctrine of Constitutional Law, 7 Harv. L. Rev. 129, 144 (1893).

35 Supra note 12, at 176. 
What gives the omission of problematic cases special force were contemporary experiences with judges. In the colonial times that Marshall knew, judges, who sometimes were also legislators, tended to be members of local power structures, with a wide range of petty responsibilities, and courts tended to be viewed as arms of the executive branch. Appointed by the crown via the governor and relying on the common law, judges were so widely distrusted that they were cited in the Declaration of Independence as a grievance contributing to the revolution, being "dependent on [the king's] will alone." Nor did this suspicion end with the creation of the republic, for judges were then viewed as favoring creditors and persons of property in their relations with the great mass of debtors. Too, federal courts had earned a reputation as eager enforcers of the notorious Sedition Act, and were seen as given to sermonizing on the citizens' duty to obey established authority. Accordingly, the opposition, which captured the presidency and Congress in 1801, viewed federal judges as allies of the executive. A judiciary independent of political influence was by no means well established by 1803, in short, and yet to it Marshall would assign the immense potential power of validating laws.

Even the Supreme Court on which he sat lacked stature. The first chief justice, John Jay, had written President Adams that he "left the bench perfectly convinced that under a system so defective it would not obtain the energy, weight, and dignity which was essential" to its performance, ${ }^{36}$ and the prophecy must have seemed sound. Indeed, the Court had heard only fifty-five cases in the dozen years before Marshall joined it; sometimes, entire sessions were cancelled; so low was its profile that the designers of the Capitol forgot to allot it space, forcing it to meet in the basement. At Marshall's appointment, Freund commented, it appeared that the "Court might languish in benign obscurity or it might go down under the lash of active contempt." ${ }^{37}$ No wonder Beveridge commented that "for perfectly calculated audacity, [Marbury] has few parallels in judicial history." 38

Second, on judicial review, Marshall finds "no middle ground," 39 but others have seen it differently. For example, in a well known dissent in a Pennsylvania case, a judge indicated that courts could declare a law void if it had been enacted in an unconstitutional manner, though review targeting the substance of laws he considered unjustified. ${ }^{40}$ Taking a different tack, the Supreme Court a century after Marshall's death, ${ }^{41}$ suggested that laws that appear to deprive discrete and insular minorities of fundamental rights would be treated differently from other laws for the purpose of judicial review. Where groups are unable to protect their rights through the political process, courts, empowered by their distance from that process, may act to assert those rights. Paradoxically, the Court implied, the counter majoritarian nature of judicial review provides courts with an opportunity to enhance democracy by voiding anti-democratic acts of majorities.

A middle ground option may also involve implementation. Marshall's decision, of course, was self implementing; if the Court cannot decide the case, it

\footnotetext{
36 George Pellew, The Life of John Jay, 337, 338 (1890).

37 Paul Freund, Foreword, in Foundations of Power: John Marshall, 1801-15, xiii (George 1. Haskins \& Herbert A. Johnson eds., 1981).

Supra note 26, at 132 .

Supra note 12, at 177.

40 Eakin v. Raub, 12 Sergeant \& Rawle 330 (Penn. 1825) (Gibson, J.).

41 United States v. Carolene Products, 304 U.S. 144, 152-53 note 4 (1938) (Stone, J.).
} 
cannot decide the case, and that is the end of it. Typically, a Supreme Court ruling is either immediately implemented or remanded to a lower court for implementation. One of the few exceptions to this procedure was Brown v. Board of Education ${ }^{42}$, which produced a second case focusing entirely on implementation. ${ }^{43}$ But in some nations, judicial deferral to the political branches is an established procedure. In Canada $^{44}$ and South Africa, ${ }^{45}$ for instance, rulings upholding same sex marriage were suspended for twelve to twenty-four months, in order that regional and national legislatures have the opportunity to modify the preexisting legislation in the interest of fairness or efficiency, so that disruption caused by the court's rulings would be minimized. In nascent democracies, where courts may be weaker, this approach may reduce the likelihood of confrontations. ${ }^{46}$ Judicial review, in short, may not be a matter of either/or.

Third, given the importance of judicial review that Marshall announced, why is there no explicit reference to it in the Constitution? That Article III made no explicit mention of mandamus, after all, is central to his argument: ${ }^{47}$ why, then, is Article III's failure to mention judicial review not even worth raising? The Judiciary Act of 1789 had been adopted by the first Congress, and fifty-one of its ninety-two members had been at the Philadelphia convention or a state ratifying convention; section thirteen had been drafted by Oliver Ellsworth, who preceded Marshall as chief justice. Was it possible that all these men, steeped in the Constitution, had failed to notice that issuing writs of mandamus was not possible under original jurisdiction? Had they acted with the knowledge that a court could undo what they had done? ${ }^{48}$

Hamilton in Federalist 78 believed that judicial review was implicit in the constitutional structure, and his arguments are often quoted. But as he took no part in the constitutional debates on the judiciary, and as The Federalist was an effort to persuade New York voters and not a record of the Framers' intentions, Hamilton's argument is not determinative. Madison's notes tell us that the Framers considered creating a council of revision, as found in New York. The council would not exercise exactly what we would consider judicial review: it would be composed of judges and members of the executive branch, it would rule on the merits and not the constitutionality of laws, and it would act before the laws were put into effect. ${ }^{49}$ Nevertheless, the council was the nearest approximation to judicial review the Framers considered, and the Framers rejected the idea. Charles Beard famously argued that the Framers favored judicial review as part of a system "primarily to

\footnotetext{
Brown v. Bd. of Educ. I, 347 U.S. 483 (1954).

Brown v. Bd. of Educ II, 349 U.S. 294 (1955).

44 Halpern v. Canada, 95 C.R.R. (2d) (2002); Hendricks v. Quebec, [2002] R.J.Q. 2506 (Can.).

45 Minister of Home Affairs v. Fourie, 1 SA 524 (CC), (S. Afr. 2006).

46 Rosalind Dixon \& Samuel Issacharoff, Living to Fight Another Day: Judicial Deferral in Defense of Democracy, N.Y.U. School of Law Public Law and Legal Theory Research Paper Series Working Paper no. 16-01 (2016).

47 Supra note 12, at 176 .

48 Ironically, a century after the adoption of the Constitution, the Court upheld another part of section thirteen on the ground that it "was passed by the first Congress assembled under the Constitution, many of whose members had taken part in the framing of that instrument." Wisconsin v. Pelican Insur. Co., 127 U.S. 265, 297 (1888).

Max Farrand, 1 Records of the Federal Convention 21 (1911).
} 
commit the established rights of property to the guardianship of a judiciary removed from direct contact with popular electorates," thinking it a check on the democratic impulses of Congress. ${ }^{50}$ Subsequent historians have examined the evidence, some rejecting it ${ }^{51}$ and others with some modifications supporting it. ${ }^{52}$ And while Doctor Bonham's Case in $1610^{53}$ was a well known instance of British judicial review, it had no progeny. The prevailing British position at the time of Marbury was expressed by Lord Chief Justice Holt in London v. Wood: "An act of Parliament can do no wrong, though it may do things that look pretty odd." ${ }^{54}$ Parliament, said Blackstone, "hath sovereign and uncontrollable authority in making, confirming, enlarging, restraining, abrogating, repealing, reviving, and expounding [all] laws." ${ }^{55}$ In an America far more prone to celebrate popular sovereignty, one might imagine that these views would resonate. But in a crowning irony, though Marshall entertains no doubts about the legitimacy of judicial review and in other cases supported his views by noting prevailing practices, his failure to highlight its history suggests that it might not have had one. Probably, the safest conclusion would seem to be that we really cannot say what the Framers intended, if they collectively intended anything at all.

Fourth, Marshall nowhere so much as hints at the identity of the Secretary of State initially responsible for delivering the commission - himself! - nor the person who failed to carry out the commission delivery assignment - his brother! Today, of course, these facts would compel a recusal. But there is no hint of any embarrassment in his opinion concerning the roles he and his brother played in the narrative nor any defensiveness or excuses or explanations offered. At one point, Marshall, speaking of Madison, avers that "It is the duty of the Secretary of State to conform to the law," ${ }^{56}$ ignoring that it was his failure to conform to the law that generated the dispute.

Politically, Marshall's opinion was a marvel. The Jeffersonians had believed that he would be impaled on the horns of a dilemma: the Court could decide in favor of Marbury, compelling Marshall to risk an impeachment that would permit Jefferson to replace him with his favorite, Spencer Roane. ${ }^{57}$ Or it could decide in favor of Madison, acknowledging the Court's pitiful weakness. What Marshall did

50 Charles Beard, The Supreme Court and the Constitution 126 (1911).

51 Robert E. Brown, Charles Beard and the Constitution: A Critical Analysis of "An Economic Interpretation of the Constitution" (1956); Forrest McDonald, We the People: The Economic Origins of the Constitution (1958).

52 Robert A. McGuire, To Form a More Perfect Union (2003); Terry Bouton, Taming Democracy: "The People," the Founders, and the Troubled Ending of the American Revolution (2007); Jac C. Heckelman \& Keith L. Dougherty, An Economic Interpretation of the Constitution Revisited, 67 J. Econ. Hist. 829 (2007).

538 Co. Rep. 114.

5412 Mod. Rep. 669, 687 (1702).

55 William Blackstone, 1 Commentaries on the Laws of England 160 (21 ${ }^{\text {st }}$ ed. 1844). A modest sort of judicial review is now exercised, as a consequence of Britain's joining the European Union in 1973, though presumably it will not survive Brexit.

56 Supra note 12 at 158.

57 In 1804 Jeffersonians impeached and removed a Federalist district court judge, John Pickering, and impeached but failed to remove a Supreme Court Justice, Samuel Chase. See Lynn W. Turner, The Impeachment of John Pickering, 54 Am. Hist. Rev. 485; Adam A. Perlin, The Impeachment of Samuel Chase, 62 Rutgers L. Rev. 725 (2010). 
was to decide in favor of Madison, thus denying the Jeffersonians an opportunity to complain, while establishing a principle they thought dangerous and unlawful. The Jeffersonians won an utterly trivial battle, denying Marbury his commission, but via Marshall's "masterwork of indirection," 58 they lost a major war, the legitimacy of judicial review, and with it the grounds for complaint.

Throughout his opinion, Marshall's approach is consistently abstract. When authorities are mentioned, they are always peripheral and ornamental. He utilizes four British references (three to Blackstone and one to Mansfield ${ }^{59}$ ) and four obscure statutes. ${ }^{60}$ Had these not been mentioned, their absence would have affected his argument not at all. Too, he shows no interest in a plethora of available wobbly precedents. The Privy Council had nullified 469 colonial laws under its power of disallowance; perhaps eight instances of judicial review at the state level had occurred under the Articles of Confederation; under the Constitution, state laws had been overturned in Ware v. Hylton (1796) ${ }^{61}$ and Calder v. Bull (1798); ${ }^{62}$ and review of congressional laws was raised in a dissent in Chisolm v. Georgia (1793) ${ }^{63}$ and by a majority that upheld the law in Hylton v. United States (1796). ${ }^{64}$ All these Marshall ignored.

\section{Marshall AND MCCULLOCH}

Consider next McCulloch v. Maryland, ${ }^{65}$ probably the most important case the Supreme Court has ever decided. Where Marbury's great principle grew out of a minor dispute of no tangible interest to any but the parties involved, McCulloch involved perhaps the greatest political issue of the day. In 1791, Hamilton, the Secretary of the Treasury and the man President Washington had placed in charge of the economy, called for the creation of a national bank. Washington was unsure whether Congress could create a bank, as the power to do so did not expressly appear in the Constitution, and so he asked Hamilton and Jefferson, his Secretary of State, for their views. Predictably, Hamilton favored the bank and Jefferson opposed it, and, predictably, Washington sided with Hamilton. Congress created the bank, but mindful of the controversy, gave it license to operate for only twenty years. From the start, however, opponents charged it with furthering the interests of northeastern financial interests and giving Britons, who owned two-thirds of its stock, more influence than the subjects of a recent war time enemy should have. State banks also became hungry for the national bank's business. The controversy attracted the leading political figures of the day, including Senators Daniel Webster of New Hampshire and John C. Calhoun of South Carolina. In the end, Congress let the bank's charter expire in 1811.

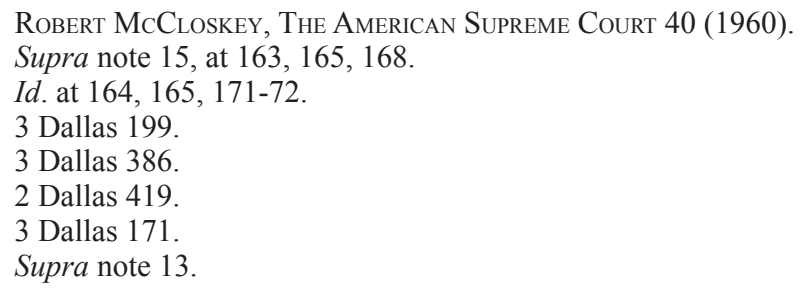


The War of 1812, however, produced economic hardship and an unstable currency, and demands began to be made for a second bank. Finally, in 1816 a second bank was established, and like the first, it was chartered for twenty years. Ineptly managed, it exacerbated the nation's economic problems, especially by contributing to the failure of many state banks and worsening what was known as the Panic of 1819, and became even more unpopular than the first bank. "Almost the whole country," as Beveridge observed, "was in grievous turmoil.".66 Several states responded with legislation banning the bank from operating within its borders or singling out its operations for taxes. One of these, Maryland, imposed a two percent tax on its bank notes, which could be waived by an annual payment of fifteen thousand dollars. This was by no means the heaviest tax imposed by states, though it was certainly significant.

On instructions from Washington, James William McCulloh (the case misspells his name), the cashier of the Baltimore branch of the bank, refused to pay the tax and was convicted for his failure to pay. The Supreme Court heard the case on appeal, hearing arguments presented by six lawyers over nine days. "The hall was full almost to suffocation," wrote Justice Story, "and many went away for want of room." ${ }^{67}$ Three days later, the Court announced its unanimous decision, featuring, as it so often did, an opinion by Marshall. As his opinion in Marbury had drawn heavily on Hamilton's Federalist 78, so his opinion in McCulloch relies on the arguments of one of the bank's chief litigators, William Pinkney. Solemnly, Marshall begins by referring to "the awful responsibility involved in [the Court's] decision" and the possibility "of hostile legislation, perhaps, of hostility of a still more serious nature." ${ }^{\prime 68}$ The political importance of the case was manifest.

Marshall announced that the case posed two questions. First, can Congress create a bank? The bank, he notes, "did not steal upon an unsuspecting legislature and pass unobserved," ${ }^{69}$ but was thoroughly discussed as early as Washington's first term. Still, Marshall concedes that the question cannot be answered simply by looking at past practice - Madison alone in Congress raised constitutional objections to the first bank, but as President in 1816, he argued for reinstating it -- and so he turns to the text of the Constitution. Here, the problem is, as Maryland pointed out, that nowhere does it mention banks. But Article I, section eight does list a number of Congress' economic powers: to lay and collect taxes, to regulate foreign and interstate commerce, to coin money, and so on. At the end of the long list, the Constitution grants Congress the power to "make all laws which shall be necessary and proper for carrying into execution the foregoing powers." 70 Marshall seizes the word "necessary," making it central to his argument. He reasons that "necessary . . . admits of all degrees of comparison," which he construes as not unduly burdening the practical workings of government. If Congress believes it is "appropriate"71 to create a bank in order to carry out its enumerated economic powers, the Court should defer to that decision unless it could be called unreasonable, which in this case it could not. It was significant, he points out, that the word "expressly,"

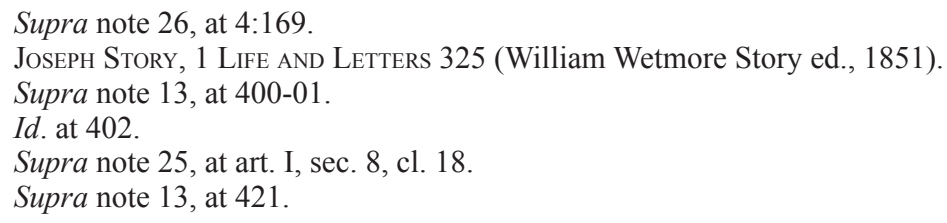


which appeared in the defunct Articles of Confederation as a limit on the central government, was after considerable discussion at Philadelphia, left out of the Constitution. ${ }^{72}$ Thus was confirmed the doctrine of implied powers.

The second question was whether Maryland can tax the bank. Maryland insisted that the issue was one of "confidence." Different governmental units routinely assume that they are confident that, in working with other units, these units will not abuse the trust placed in them. The bank should be confident that Maryland will not misuse its taxing power. To which Marshall replies icily, "All inconsistencies are to be reconciled by the magic of the word CONFIDENCE."73 The question was not confidence, he says, but rather whether a part should control the whole. ${ }^{74}$ When Maryland taxed the bank, it taxed an institution created by the whole nation. And as "the power to tax involves the power to destroy" 75 - here, he repeated the words of Daniel Webster, one of the bank's lawyers -- the power Maryland asserted was impressive, indeed. "The states have no power, by taxation or otherwise, to retard, impede, burden, or in any manner control" the national government. ${ }^{76}$ Were the states' to have grasped that their powers were so seriously limited, said Luther Martin, Maryland's chief lawyer, they might well have refused to adopt the Constitution, ${ }^{77}$ but his point was lost.

As with Marbury, we can imagine Marshall posing two questions. Again, is this a constitution? Of course, he answers. "We must never forget that this is a Constitution we are expounding . . . a Constitution designed to endure for ages to come." ${ }^{.78}$ Its very nature, "therefore, requires that only its great outlines should be marked, its important objects designated, and the minor ingredients which compose those objects be deduced from the nature of the objects themselves." 79 If it is not to become a "splendid bauble," 80 the Constitution must be interpreted in ways that avoid "the absolute impracticability of maintaining it without rendering the government incompetent to its great objects." ${ }^{11}$ This requires that Congress be given broad discretion in determining what is necessary and proper to carry out its powers. Again, is this a court? Of course, and so its job is to say what the law is. And because it is in its nature that a constitution be "the supreme law of the land," any state law contrary to it must give way. With this, he established the principle of national supremacy.

Consider how Marshall massages "necessary," extracting meaning after meaning in no fewer than eighteen pages, while never bothering to consult a dictionary or any other source. Jefferson, in arguing against the first bank, had seen "necessary" as meaning "The One Thing We Must Do or the Sky Will Fall." 82 Yet Marshall begins by speaking of "necessary" as embodying "the most appropriate

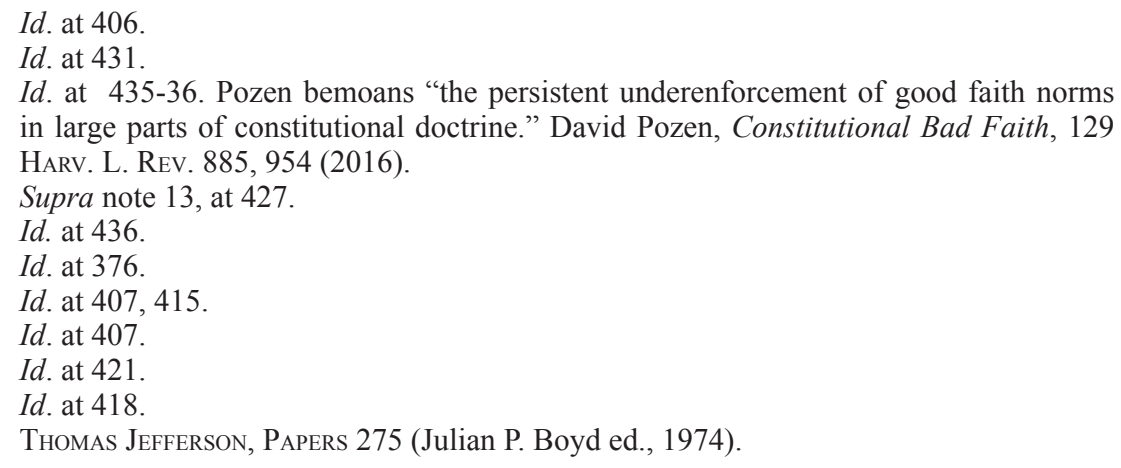


means," $" 83$ but then moves on to claim that it "has not a fixed character [but] admits of all degrees of comparison" " 44 : A thing may be necessary, very necessary, absolutely or indispensably necessary," 85 and "frequently imports no more than one thing is convenient, or useful, or essential to another." ${ }^{86}$ In reaching this result, he refers to "the common affairs of the world," unnamed "approved authors," 87 and "the character of human language," as well as a provision of Article I that uses the term "absolutely necessary." "To employ the means necessary to an end is generally understood as employing any means calculated to produce the end," he concludes, "and not as being confined to those single means without which the end would be entirely unattainable." 89 This "must have been the intention of those who gave these powers to insure, so far as human prudence could insure, their beneficial execution." ${ }^{90}$ Thus, where in Marbury, Marshall insisted on the Court's power to say what the law is, in $\mathrm{McC}$ Culloch he comes perilously close to assigning that power to Congress. The constitutional term "necessary," in this way, is transmuted into "any appropriate means"91 or "the best means"92 or "any means adapted to the end," ${ }^{93}$ which raises a question he never confronts: If the Framers meant to so empower Congress, why did they choose "necessary"?

All these difficulties are dismissed by announcing that "this is a Constitution we are expounding," which Marshall believes requires flexibility. But if flexibility is the trump card, why even have a constitution? Why not have only ordinary statutes, which may be altered or reversed without recourse to the extraordinarily cumbersome process of amendment? This, in turn, suggests a competing view: suppose the point of a constitution is not to be flexible, but rather to set down fixed principles. This would explain why it cannot easily be changed, and it would also imply that courts should not be so free to rewrite it. For the clause says that Congress can "make all laws that shall be necessary and proper," not all laws that it considers necessary and proper. On the other hand, though the Constitution is silent as to who should enforce the necessary and proper standard, the courts would seem to have a better claim than Congress, which would be tasked with policing itself. ${ }^{94}$ Also, that the term refers not only to the "foregoing [enumerated] powers," but also to "all other powers," might suggest a broader application, for the language is so sweeping and without boundaries that it appears to invite very broad application. Thus, Hamilton relies on this phrase as well as necessary and proper in his justification of the bank..$^{95}$

\footnotetext{
Supra note 13 , at 408 .

Id. at 414.

Id.

Id. at 413.

Id.

Id. at 414.

Id. at 413-14.

Id. at 415.

Id. at 410 .

Id. at 415 .

Id. at 419 .

James Wilson, the Framer responsible for the phrase, was a strong proponent of judicial review. Mark David Hall, The Political and Legal Philosophy of James Wilson, 17421798 134-38 (1997).

95 Alexander Hamilton, 9 Papers 103 (Harold C. Syrett \& Jacob E. Cook eds., 1965).
} 
Marshall assumes that the necessary and proper clause "purports to enlarge" Congress' powers ${ }^{96}$ constituting what we call the elastic clause. One retort might be that, instead, the clause limits Congress to implementing its enumerated powers only by means that are necessary and proper. Marshall finds it relevant that the Constitution contains "no phrase [that] excludes incidental or implied powers," but there was no phrase that excluded writs of mandamus from the Court's original jurisdiction in Marbury, and its absence did not save the law.

The larger problem with the elastic clause assumption is that Marshall in truth has demonstrated something very different, namely, that the power to create a bank could be inferred from the listed economic powers, even without the final clause. For if it is the nature of constitutions that they be interpreted broadly, they would grant legislatures the power to implement powers, even if implementation were unmentioned. Underlining this, it was established at common law that an express power carries with it incidental powers, a fact that Marshall even refers to in passing. ${ }^{98}$ If Congress can "establish post offices and post roads, ${ }^{\text {"99 }}$ for instance, as he points out, it can aIso provide that mail shall be carried on these roads and that those who rob the mail shall be punished. ${ }^{100}$ That the necessary and proper clause was superfluous was expressed by Hamilton in Federalist 33 ("it may be affirmed with perfect confidence that the constitutional operation of the intended government would be precisely the same, if these [necessary and proper] clauses were entirely obliterated") and Madison in Federalist 44 ("Had the Constitution been silent on this head, there can be no doubt that all the particular powers requisite as means of executing the general powers would have resulted to the government by unavoidable implication"). Was Marshall making something out of nothing?

Maryland had contended that the necessary and proper clause merely gave Congress the power to legislate in pursuance of the expressed goals. Marshall thought that reading it as giving a legislature the power to legislate was so obvious that it would add nothing to the Constitution. "Would it have entered into the mind . .. of the convention," he asked, "that an express power to make laws was necessary to enable the legislature to make them? That a legislature endowed with legislative powers, can legislate is a proposition too self-evident to have been questioned."101 But the same charge of superfluity could be leveled at his argument: If Congress already had incidental powers, why add a necessary and proper clause?

The reach of what constitutes "incidental powers," however, may be contested, partly because they apply to an uncertain future, as Madison noted in Federalist 44, but also because the Constitution was not straight forward on the question. For example, as Luther Martin pointed out, the Constitution not only granted Congress the power to declare war, but also to raise an army, even though that would seem

\footnotetext{
Supra note 13, at 418-19.

Id. at 406.

Id. at 416.

Supra note 25, art.I, sec. 8, cl. 7.

100 Supra note 13, at 417. This was a potent example. In 1816, sixty-nine percent of national civilian employees were postmasters, and "for the vast majority of Americans the postal system was the central government." Richard R. John, Spreading the News 3, 4 (1995).

101 Supra note 13, at 413.
} 
to be incidental to the war power. ${ }^{102}$ In addition, as Madison indicated, incidental powers needed to be distinguished from "independent and substantive powers," 103 which Marshall does. ${ }^{104}$ Madison thought the power to charter corporations, including creating banks, was an independent and substantive power. Hamilton, who favored the bank, disagreed. ${ }^{105}$ The difference between incidental and independent and substantive, Marshall asserts, is that the former refer to means and the latter to ends. In fact, though, all government powers refer to means. Government is not an end in itself, but a means toward some other end, perhaps security or prosperity or justice. Thus, in practice, the distinction may be difficult to maintain. For example, when Congress passed a law banning guns from schools on the theory that gun-free schools would contribute to education and thus to interstate commerce, a divided Supreme Court thought the connection too insubstantial to sustain. ${ }^{106}$

Jefferson, in arguing against the first Bank of the United States had contended that creating a bank was not an incidental power, that the Framers rejected giving Congress the power to create a bank for fear of an "adverse ... reception [from] the great cities," and that construing "necessary" to mean "convenient" "would swallow up all the delegated powers. As he remarked in 1800 about a bill providing for congressional incorporation of a New Jersey copper mine, "Congress are authorized to defend the nation. Ships are necessary for defense; copper is necessary for ships; mines, necessary for copper; a company necessary to work the mines; and who can doubt this reasoning who has ever played at 'This Is the House that Jack Built'?"'107 What limitations on congressional power are left? Marshall acknowledges that "Congress, under the pretext of executing its powers, [might] pass laws for the accomplishment of objects not intrusted to the government," 108 but in context this seems to him a remote possibility, theoretically conceivable but no more than that, for courts ordinarily do not inquire into the motives of legislatures but only into their intent. Nor does Marshall even concede the constitutional relevance of unintended consequences. When discussing the strict scrutiny doctrine in the context of apparent racial discrimination, for example, modern courts insist that the state have a compelling interest and that the legislation be narrowly tailored, all to make sure that rights are abridged no more than necessary. These concerns do not interest Marshall. His heart clearly belongs to Congress.

Yet it was not the necessary clause. It was the necessary and proper clause. How to parse the phrase? Should it be construed to hold that "necessary" refers to the end sought by the legislation and "proper" to the means; or, conversely, "proper" to the end and "necessary" to the means? Either way, the statute would have to surmount two hurdles. Thus, in the Affordable Care Act case, Chief Justice Roberts held that the individual mandate might be "necessary" to the statute's purpose, but was "not a 'proper' means for making these reforms effective." 109 An

\footnotetext{
102 This, however, ignores that an army may have other rationales, such as helping in cases of natural disasters or other public emergencies.

103 James Madison, 13 Papers 372, 375-79 (Charles F. Hobson ed., 1981).

104 Supra note 13, at 411.

105 Supra note 103, at 8:100-01.

106 United States v. Lopez, 514 U.S. 549, 561 (1995).

107 Charles Warren, 1 The Supreme Court in United States History 501 (1926).

108 Supra note 13 , at 423.

109 NFIB v. Sebelius, 132 S. Ct. 2566, 2592 (2012).
} 
extensive historical investigation of the clause agrees that the "separate insertion of the word 'proper' strongly suggests that it had a meaning separate from necessary, and almost certainly a restrictive one." 110

Marshall, however, touches on "proper" only in a single paragraph, declining even to mention the word ${ }^{111}$ and satisfying himself with the assertion that "it would be an extraordinary departure from the usual course of the human mind" to use the word "to qualify that strict and rigorous meaning" of "necessary." 112 This is really not an argument but an effort to dispense with making an argument. One authority contends that Marshall evidently saw necessary and proper as a hendiadys, a figure of speech, in which words joined by a conjunction convey a single meaning, for example, calling a pie "nice and tasty"; "nice" does not duplicate "tasty," but reinforces it in a vague way; is the pie minimally tasty? is it the tastiest pie imaginable? The possible meanings are so capacious, it is impossible to say. Thus did "proper" reinforce "necessary," he claims, leaving a wide range of possible meanings: "Congress has the incidental powers that are proper to each of its enumerated powers precisely because they are needed to carry those enumerated powers into execution." 113 Similarly, a careful examination of the contemporary usage of the phrase concludes that it was not a technical legal term, "but rather a common feature of ordinary English." 114 The implication is that courts should focus on "the fit between an agent's prescribed ends and chosen means." 115 But this would seem to entail considerable judicial discretion, a possibility Marshall does not entertain. The effect on the reader, finally, is to be barraged and ultimately overwhelmed by the rat-tat-tat of arguments. Likely exhausted, we surrender and admit defeat.

That Maryland cannot tax the bank seemed to Marshall a question that required a much briefer response. Of course, Congress was empowered to bar states from taxing the bank, leaving Marshall free to pass the burden of deciding onto the political process. But even in the absence of this legislation, he found the states barred by the Constitution itself. The central government, he said, "represents all, and acts for all [and] must necessarily bind its component parts," a fact made explicit by the supremacy clause that makes "the Constitution, and the laws of the United States, which shall be made in pursuance thereof . . the supreme law of the land." 116 Although the Constitution does not explicitly prohibit states from taxing or otherwise interfering with operations of the national government, the broad principle of national supremacy rules them out. If Maryland were to prevail, the national government would be left prostrated "at the foot of the states," and the supremacy clause would in effect be rewritten to "transfer the supremacy, in fact, to the states." 117 The point, according to Wechsler, "was the maintenance of national supremacy against nullification or usurpation by the individual states, the national

110 Gary Lawson et al., The Origins of the Necessary and Proper Clause 93 (2010).

111 Supra note 13, at 418-19.

112 Id., 419.

113 Samuel L. Bray, "Necessary AND Proper" and "Cruel AND Unusual": Hendiadys in the Constitution, 102 VA. L. REV 687 (2016).

114 John Mikhail, The Necessary and Proper Clauses, 102 Geo. L.J. 1045, 1115 (2014).

115 Supra note 113, at 67.

116 Supra note 25, art. VI, sec. 2.

117 Supra note 13, at 432. 
government having no part in their composition or their councils." ${ }^{118}$ But if the national government requires protection against the states, Marshall sees no need for the reverse to apply.

As with Marbury, McCulloch presented a clear and obvious case. There could be no question that the congressional and Maryland laws were in conflict. But what if the conflict were not beyond dispute? In Pennsylvania v. Nelson (1957), ${ }^{119}$ for example, the state contended that its purpose was to support, not contravene the congressional statute. The Supreme Court, in striking down the Pennsylvania statute, emphasized that Congress had a dominant interest in the topic and had created a pervasive system of regulation, and that there existed the possibility of conflict in administration. All this suggested to the Court that Congress, which was silent on the subject in the law, had intended to preempt the field, leaving no room for the states. ${ }^{120}$ Marshall's task was to establish the fundamental principle of national supremacy. Difficult issues of detail were beyond his purview.

Maryland had contended that the national government was created by the states, as was true under the Articles of Confederation. The members of the convention were elected by state legislatures, and ratification took place on a state-by-state basis. But Marshall replies that, instead, it "proceeds directly from the people," 121 as the preamble's famous opening phrase, "We the people," announces. He concedes that when the people act, "they act in their states. But the measures they adopt do not, on that account, cease to be the measures of the people themselves, or become the measures of the state governments." ${ }^{122}$ To which one is tempted to ask, why not? If the state is the basic decisional unit and not, as he noted, "the American people [in] one common mass," ${ }^{23}$ why persist in claiming the reverse? Marshall, though clearly correct, did not stoop to confront the inconvenient details supporting his opponents.

McCulloch not only established implied powers and national supremacy, but the very act of deciding cemented the principle that the Court shall serve as the umpire deciding disputes between the different levels of government. As a court, whose first task must be to say what the law is, it can determine when an act of Congress conflicts with a state law, and declare it unconstitutional. Years earlier during the ratification process, Anti-Federalists had predicted that the "judicial power will operate to effect . . . an entire subversion of the legislative, executive and judicial powers of the individual states" 124 because they believed that national courts would invariably side with the national government against the states. Delineating the boundaries between the two levels, however, has emerged as one of the Court's most important functions, and the national level by no means always wins (e.g., Chamber of Commerce v. Whiting ${ }^{125}$ ). Still, though McCulloch may have settled vital constitutional questions, the key remaining political question - is the

118 Herbert Wechsler, The Political Safeguards of Federalism: The Role of the States in the Composition and Selection of the National Government, 54 CoL. L. REv. 543, 544 (1954).

119350 U.S. 497.

120 Some members of Congress vehemently disagreed. See, e.g., 104 Cong. Rec. 14139-40.

121 Supra note 13, at 403.

122 Id.

123 Id.

124 Herbert Storing, 2 The Complete Anti-Federalist 420 (1981).

125563 U.S. $582(2011)$. 
nation a compact of states permitting secession or a permanent federal system was not resolved until the Civil War nearly a half century later, which followed generations of controversy (the Virginia and Kentucky Resolutions of 1798 provoked by the Alien and Sedition Act, the Hartford Convention in response to the War of 1812, South Carolina's Statute of Nullification in 1832 reacting against the Tariff of Abominations). Indeed, McCulloch helped to "call into action a Southern states' rights movement that dominated politics from the 1820 s to the Civil War."126

\section{Marshall AND GibBONS}

The third great case decided by Marshall, Gibbons v. Ogden, ${ }^{127}$ saw a private dispute elevated to national importance. The case involved navigation of the Hudson River, which divided New York from New Jersey. New York, by then the most populous state, had enacted legislation purporting to claim the river as entirely its own, and New Jersey had responded by asserting a right to seize New York steamboats that docked on their shore; in short, commercial warfare of exactly the kind the Constitution was designed to prevent had begun.

In this context, Robert Livingston and Robert Fulton were granted an exclusive right by New York to steamboat navigation within its waters, and they assigned the right to Aaron Ogden and Thomas Gibbons. Their arrangement, however, dissolved, and an angry Gibbons obtained a license from Congress to operate his steamboat between New York and New Jersey on the Hudson River. Ogden won an injunction from a New York court that would restrain Gibbons from navigating New York waters; the order was upheld on appeal. Ogden successfully argued that the Constitution did not explicitly grant Congress exclusive control over commerce; states historically, on the other hand, enjoyed exclusive power to regulate commerce within their borders; commerce, in any event, did not include navigation. ${ }^{128}$ Gibbons responded by taking the case to the Supreme Court.

In the larger context, a number of other states were at the time asserting the power to regulate navigation, and the question as to whether Congress could appropriate funds for transportation infrastructure ("internal improvements," in the language of the day) was a topic attracting great public attention. The principle of national supremacy announced five years earlier in $M c C$ Culloch would seem to guarantee that Gibbons would prevail, but this, in turn, required that the congressional license be valid. The entire case pivots on that question, which brings Marshall to an inquiry as to the meaning of the commerce clause: "The Congress shall have the power ... to regulate commerce . . . among the several states." 129

The deteriorating commercial state of the nation had been perhaps the key factor in replacing the dysfunctional Articles of Confederation with the Constitution. Commercial dissatisfaction had led to the failed Annapolis Convention in 1786 and then to the Philadelphia convention the year after. Oddly, however, this topic

126 R. Kent Newmeyer, A Judge for All Seasons, 43 WM. \& MARY L. Rev. 1463 (2002).

127 Supra note 14.

128 17 Johns. 488 (NY 1820).

129 Supra note 25, art. I, sec. 8, cl. 3. 
of immense importance received only cryptic treatment in Article I. Marshall in Gibbons took it upon himself to add flesh to the bones.

Marshall begins by admitting that New York's position "is supported by great names," whose opinions are entitled to "a just and real respect." ${ }^{130}$ But turning to the Constitution, he then asks why it should be construed strictly, in particular, why "commerce" should be limited "to traffic, to buying and selling, or to the interchange of commodities" and exclude navigation. ${ }^{131}$ The Constitution itself is silent as to how it should be construed, but historically navigation "has been understood by all to be commercial regulation," 132 and was so understood by the Framers. In fact, one provision of Article I speaks of "regulation of commerce" and "ports," indicating that "commerce relates to navigation." 133 Alluding to Jefferson's embargo of British ships from 1807-1809, Marshall cites it as an example of commerce as navigation, ${ }^{134}$ reminding the reader of his foe's failed and unpopular policy and using it for his own purposes. Commerce, he concludes, encompasses "intercourse," 135 a term broad enough to cover traffic, buying and selling, navigation, and presumably much more. As with "necessary" in $\mathrm{McC}$ Culloch, Marshall's definitional exegesis proceeds without reference to dictionaries or other formal authorities.

Marshall then considers the meaning of "among the several states," finding that "among" means "intermingled with" and the entire phrase "commerce which concerns more states than one." 136 Commerce "which [is] completely within a particular state [and which does] not affect other states [and] which it is not necessary to interfere for the purpose of executing some of the general powers of the government" would be reserved for the states. ${ }^{137}$ Commerce, then, cannot only be regulated by Congress at the imaginary "mathematical line" separating states, but must be within states. ${ }^{138}$

Next Marshall defines "regulate" as "the power . . to prescribe a rule by which commerce is to be governed." What kind of rule? Any kind, for "the power . . . is complete in itself, may be exercised to its utmost extent, and acknowledges no limitations other than are prescribed in the Constitution."139 The power of Congress, "though limited to specified objects, is plenary as to those objects." ${ }^{140}$ Does this mean that the states have no power to regulate commerce with interstate implications? Daniel Webster had advocated this position in his oral presentation, and the nationalist, Justice William Johnson, supported it in his concurrence. The commerce clause needed to be interpreted in light of the disastrous interstate commercial warfare that it was intended to curb, he argued, ${ }^{141}$ and so he would bar New York from asserting navigation rights over the Hudson, even in the absence of a congressional statute. ${ }^{142}$

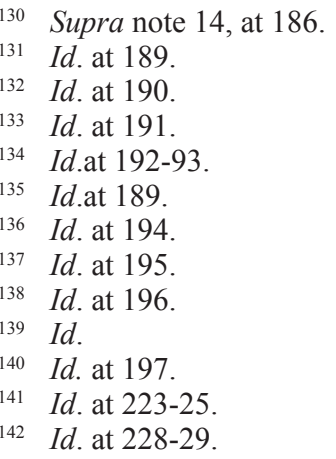


Did New York run afoul of the Constitution or merely an act of Congress? Marshall addresses the question with diplomatic ambivalence. "There is great force to this argument," ${ }^{143}$ he conceded, but it is not necessary to rule on the matter here. The Court did not have to decide whether the Constitution barred the state from acting because Congress had adopted a law with that effect. ${ }^{144}$ Having established by parsing the commerce clause that Congress may license Gibbons, he concludes that "the acts of New York must yield to the law of Congress."145

The opinion is long on historical assertions, but short on historical evidence, and, oddly, repeatedly refers to "express" constitutional powers, when in McCulloch he had emphasized how important it was that the Framers after much deliberation had discarded that word, which had so severely limited the central government under the Articles of Confederation.

Again, we can easily imagine Marshall asking, Is this a constitution we are discussing? We must answer, yes, and here he pounces: a "narrow construction . . . would cripple the government and render it unequal to the object for which it is declared to be instituted." 146 The nature of a constitution requires a broad interpretation. What is most startling to the modern reader are the future implications of his reading of the commerce clause. In his day, it might authorize the national government to embark on the infrastructure projects that many political figures believed were essential for the nation's economic development. And yet the America of the first quarter of the nineteenth century was an agricultural nation dominated by local and to a much smaller extent regional markets. The national communications and transportation networks that today tie the enormous country together barely existed, and government itself was not very ambitious. Now, when all this has radically changed, the commerce clause supplies the constitutional rationale for a vast array of statutes and regulations, often with important noncommercial rationales. Marshall's foresight, given this, appears remarkable.

Yet did his prescient interpretation of the commerce clause follow from the meaning the words then carried? The most thorough originalist investigation suggests that the answer is no. ${ }^{147}$ Barnett examined every mention of the term "commerce" at the constitutional convention, at the ratification debates, and in the Federalist, and found no example of the word given a broad Marshallian meaning; he also looked at every instance in which a representative newspaper, the Pennsylvania Gazette, used the term from 1728-1800 to ascertain what ordinary citizens meant. ${ }^{148}$ Again, none was unambiguously broad. "Commerce" referred to trade or exchange, including shipping, but never to the vast list of activities contemplated by Marshall's "intercourse." Similarly, "regulate" meant "to make

43 Id. at 209.

144 Primus speculates that Marshall may have drawn back from the constitutional argument from a fear that it might have undermined the South's ability to regulate slavery. Richard Primus, Marshall's Enumeration, University of Michigan Public Law Research Paper no. 496, 43 (2016).

145 Supra note 14, at 210.

146 Id. at 189.

147 Randy E. Barnett, The Original Meaning of the Commerce Clause, 68 U. CHI. L. REV. 101 (2001).

148 Randy E. Barnett, New Evidence of the Original Meaning of the Commerce Clause, 55 ArK. L. REV. 847 (2003). 
regular," not to prohibit. Government may instruct us: if you want to carry on a certain commercial activity, this is how you must proceed, but it may do no more than that. Though Marshall sometimes referred to the Framers, Barnett argues that he was not squeamish about placing his own views above theirs. Similarly, President Madison, the Father of the Constitution, vetoed an internal improvements bill, arguing that the commerce clause did not permit Congress to improve navigation because "Such a view of the Constitution would have the effect of giving to Congress a general power of legislation, instead of the defined and limited one hitherto understood to belong to them." 149 Notwithstanding these originalist considerations, of Marshall's great opinions Gibbons was the most popular, the public's applauding "its effect in shattering the great [steamboat] monopoly against which they had been struggling for fifteen years." 150

\section{Marshall AND FLETCHER}

Consider, finally, Fletcher v. Peck, which involved one of the greatest corruption scandals in early American history, the Yazoo land scandal. In 1795 Georgia sold a vast tract of public land known as the Yazoo lands, nearly as large as the states of Alabama and Mississippi, to land speculators for five hundred thousand dollars, about three cents an acre. Why such a bargain price? Almost the entire Georgia legislature had been bribed by the speculators in what Marshall's biographer called "a saturnalia of corruption." 151 As the speculators resold the land at a handsome profit to buyers who may have been unaware of the bribery, Georgians began to agitate against the initial purchase, a mob at one point even threatening to lynch the legislators. ${ }^{152}$ In 1796 a new legislature was elected that asserted a power to decide on behalf of the people whether past laws were valid. Accordingly, in 1796 it passed a law declaring the purchase null and void. The original act, as the product of fraud, had never been valid. After many failed efforts at compromise, Georgia's 1796 rescinding act was tested before the Supreme Court in Fletcher v. Peck. John Peck sold Robert Fletcher 15,000 acres of the disputed land; Fletcher challenged Peck's title to the land, given the 1796 law. (Actually, it was a collusive suit, as both parties hoped that the claim would be upheld because both were speculators with land to sell; if the 1796 law were upheld, their land titles would be worthless.)

Marshall deplores the apparent corruption, but then quickly dismisses it as irrelevant, for it would be "indecent in the extreme" for courts to inquire as to the "impure motives" of legislatures. In this, he followed the standard practice of ignoring motivation and focusing on intent. The Georgia constitution did not bar the sale of land to the speculators, and Georgia cannot undo the sale by declaring the operative law never to have been valid because the original 1795 law can be considered a contract, and the Constitution denies states the power to impair the

\footnotetext{
2 Messages and Papers of the Presidents 569 (James Richardson ed., 1897).

Supra note 107, at I:75.

Supra note 28, at III:548.

152 Joel Chandler Harris, Georgia from the Invasion of DeSoto to the Present Day 130 (1896).
} 
obligation of contracts. ${ }^{153}$ Moreover, by declaring the law invalid, the legislature was asserting a power that properly belonged to the courts. Peck, therefore, had title to the land, and was free to sell it to Fletcher. The 1796 rescinding act violated the United States Constitution, the first important time a court had ruled a state law unconstitutional. In this regard, Marshall, following Federalist $82,{ }^{154}$ concedes that state courts may hear cases on federal law, but insists that the losers in such cases retain the right to appeal to federal courts. This was a principle guided by practicality: there were not enough federal courts to monopolize federal cases, and yet if the final determination were not made by a federal court, the uniformity required of federal law would be impossible.

Again, we can imagine Marshall posing simple questions. What is a contract, he asks? It is a compact that binds the participants to do a particular thing. When Georgia sold the Yazoo lands, it bound buyer and sellers, and thus was a contract, and as such, it came under the authority of the contract clause. Well, then, is this a court? Yes, he replies, and so it is up to us to say what the law is. Legislatures may change their mind and repeal laws, but they cannot declare laws null and void, as if they never had been enacted. This power belongs to the courts. Finally, is this a constitution? It is, and so it represents the entire union, and must prevail over a single state that is merely a member of the union. The Georgia legislature, then, by impairing the obligation of contract, exceeded its authority.

Interestingly, Marshall emphasized the intent of the Framers as to the contract clause. The impairment of contract, he wrote, was common under the Articles of Confederation, contributing to a climate of uncertainty about property rights that helped to bring about the Constitution itself. A robust interpretation of the clause was exactly what the Framers' Constitution called for. ${ }^{155}$ If states were free to undo contracts, fundamental property rights - and with them, liberty itself - would be imperiled. "The past cannot be recalled," 156 he wrote, and efforts to do so could only generate instability. States' political concerns, even when freighted heavily with apparent common sense, cannot trump the law. Inquiry into legislative motivation was therefore out of bounds.

What did Marshall omit? He never addresses the notion that the contract clause might apply only to private parties, though the imperfect legislative history reveals that the Framers spoke of the contract clause only in this sense. The implication of extending its application to states is that their range of future action would be limited by property rights asserted by private parties. Marshall discusses the practical imperative of protecting these rights, but never acknowledges the cost, preventing democratically elected officials from undoing certain kinds of past actions in the name of the public interest. Today, abrogating public contracts is harder than private contracts. ${ }^{157}$

Citing "certain great principles of justice," 158 Marshall rules that an innocent purchaser should not suffer for the guilt of another. In this sense, his opinion

\footnotetext{
Supra note 25, art. I, sec. 10, cl. 1.

Supra note 1.

155 He could not draw on Madison's records of the debates to support this contention because they would not be published until 1819 .

156 Supra note 15 , at 135.

157 United States Trust Co. v. New Jersey, 431 U.S. 1 (1977).

158 Supra note 15, at 133.
} 
reiterated a well established principle of English law. Switching to practicalities, he continues, if this were permitted, "all titles" would be insecure. That this might incentivize corrupt parties, who would no longer confront buyers uncertain if their title would be honored, is not considered. But this construes the contract clause in absolute terms, ignoring that enforcement may be refused if the agreement was procured through bribery. When Marshall declines to examine the motivations of the parties, he forecloses the possibility of determining whether this ground for unenforceability existed. ${ }^{159}$

Also, though Fletcher and Peck in truth had identical interests, Marshall fails to rule that the case was collusive, and thus did not meet the constitutional requirement of legitimate "case or controversy" and should not have been heard by the Court. ${ }^{160}$ In the adversarial system, one party may be relied upon to check the other; collusive cases, on the other hand, are left for courts to determine because by definition both parties are involved in the conduct and will not raise the issue. Here, Marshall is so intent on construing the contract clause that he ignores the collusion. In a concurrence, Justice Johnson notes that he was reluctant "to proceed" since it had the markings of a "feigned case," but did so only because he concluded that "the respectable gentlemen ... would never consent to impose a feigned case on this court."'161

\section{Some Conclusions}

What can we infer from these four major cases? Marshall, though his formal legal education consisted only of six weeks of lectures at the College of William and Mary, developed a supremely effective voice, confident ("The answer to this question seems an obvious one," "perfectly clear," "a proposition too plain to be contested," "too apparent for controversy"), straight forward ("Has the applicant a right to the commission he demands"? "The plain import of the words", "It is emphatically the province and duty of the judicial department to say what the law is"), and unequivocal ("The doctrine would subvert the very foundation of all written constitutions," "it thus reduces to nothing what we have deemed the greatest improvement on political institutions," "it thus must have been the intention"). He was not above bluster and bullying ("he would be charged with insanity," "an extraordinary departure from the usual course of the human mind," "no reason has been or can be assigned," "If any one proposition could command the universal assent of mankind"). He used strong, active verbs ("requires," "denies," "directed"), disdained qualifiers ("emphatically", "absolutely incapable," "no reason to suppose," "truths which have never been denied"), and often refuted counter arguments by ignoring their existence.

59 Interestingly, Marshall himself had engaged in land speculation.

60 Supra note 25, art. III, sec.2, cl.1.

161 Supra note 15, at 147-48. In 1814, Congress compensated the Yazoo property holders at about an eighth of the value the Court had approved. C. Peter McGrath, Yazoo: Law and Politics in the New Republic 99-100 (1966). 
Judge Posner counts Marshall as a "notable example "of the impure style,"162 by which he means discourse that is less formal and more conversational than the standard. His language, according to Story, favored "general principles and comprehensive views, rather than . . . technical or recondite learning." 163 Apart from a few terms ("detinue," "mandamus," "estopped"), it would have been easily understood by any educated layperson of the time. And though he was drawn to prolonged focus on key words, particularly, constitutional words, for example, "constitution," "necessary," and "commerce," his discussions were never obscure. Instead, they turned on what he plainly thought were common sense considerations. In this, he followed the lead of his contemporary, Bentham, who, believing that lawyers and judges used linguistic complexity and arcana for their own purposes, favored plain writing comprehensible to ordinary people. 164 "Impure stylists," according to Posner, "like to pretend that what they are doing when they write a judicial opinion is explaining to a hypothetical audience of laypersons why the case is being decided in the way that it is." 165 The effect is frankness and authenticity: we are reading the writer's true thoughts and feelings, and this contributes to its authoritative impact.

At the same time, however, Marshall's voice could be oracular like the voice of God, intimidating and conversational only in the sense of a superior dressing down a subordinate. For the overpowering sense in the reader is inevitability. Marshall presents himself as compelled by logic, history, and common sense, as if an automaton in thrall to these forces. "Certitude," Holmes warns, "is not the test of certainty," 166 but Marshall is not convinced. The problem he faces never in his view, the problem he constructs - is reduced to a series of rhetorical questions that guide the narrative to the desired result. Occasionally, he will admit the existence of choice, as whether states retain a role in regulating commerce, but for the most part his opinions concede no alternative path. Solan observes that "The more difficult it is for a judge to state in his opinion what drove him to the decision the more tempting independent noncontroversial argument becomes, such as arguments based on our knowledge of language." ${ }^{\prime 67}$ He regards this as a kind of "linguistic sleight of hand,"168 contra Bentham, and others perhaps might read it as a sign of egoism. More plausibly, however, it seems to have been for Marshall a practical response to the counter-majoritarian difficulty. Were judges openly to place their views over those of the people's elected representatives, they would reek of illegitimacy. But if they, instead, announce that it is the law, speaking objectively, clearly, and unambiguously, the problem is avoided. And because Marshall was so clearly comfortable with who he was, his voice is unencumbered with disguises

162 Richard A. Posner, Judges Writing Styles (And Do They Matter?), 62 UnIv. ChI. L. Rev. 1421, 1430 (1995).

163 Edward S. Corwin, John Marshall and the Constitution 116 (1919).

164 Jeremy Bentham, 5 Works 22-24 (John Bowring ed., 1839). An analysis of the readability of over six thousand opinions written since 1940 reveals an upwards trajectory in the length of sentences and the use of long, polysyllabic words, suggesting perhaps that Bentham's fears have been realized. Ryan Whalen, Judicial Gobbleygook: The Readability of Supreme Court Writing, 125 Y ALE L. J. Forum 543 (2015).

165 Posner supra note 162, at 1430.

166 Oliver Wendell Holmes, JR., Collected Legal Papers 311 (1920).

167 Lawrence M. Solan, The Language of Judges 276 (1993).

$168 I d$. at 178. 
and folderol and strikes us as unmistakably authentic. There is simply nothing false about it. His judicial voice was in harmony with his true self.

A persistent theme is Marshall's use of the rhetorical device known as redescription or reframing, which is employed to change the meaning of key terms or concepts. Plato and Aristotle used this technique to attack the rhetoric of their predecessors, as Marshall doubtlessly knew from his early reading in the classics. In the Meno, for example, Plato has Socrates redescribe "fine things" as "good things," perhaps to avoid the upper class implications. ${ }^{169}$ Machiavelli also used redescription to redefine the virtues needed to attain and maintain power, moving from platonic Christianity to consequentialist means/ends rationality, ${ }^{170}$ and Hobbes used it to redefine virtue and vice. ${ }^{171}$ In the same way, Marshall cajoles the reader into accepting the legitimacy of his constitutional reasoning. Consider how he redescribes "original jurisdiction," "necessary," "commerce," "regulate," "contract," even "among." Options are chosen and rejected, meanings are shifted or reweighted, and the illusion of transparency generated by his straight forward prose distracts us, so that we fail to notice our manipulation.

Marshall also makes use of paradiastole, which was also found in ancient and Renaissance rhetoric. An example might be to use "courageous," when others might use "foolhardy." Thus, Marshall repeatedly insists that the national government must be strong in order to do all that it is charged with doing. That his "strength" is Jefferson's "overbearing dominance" is barely mentioned, for the device enables him to beg the question. Which suggests that redescription and paradiastole were employed both by Marshall and his adversaries.

Whereas today, months pass between oral argument and written opinion, in Marshall's time the gap was often astonishingly short. Of sixty-six constitutional cases generating full opinions from 1815-1835, seventeen were handed down within five days. ${ }^{172}$ Marshall's famous $\mathrm{McC}$ Culloch opinion appeared after only three days. Thorough informal discussion, perhaps at the boarding house where the justices resided when the Court was in session, seems to have obviated the need to circulate drafts of the opinions formally. There can be little doubt that Marshall's remarkable writing facility enhanced his influence: when he assigned opinions to himself, they were done quickly.

Marshall, then, understood the power of the word. But he also understood its limitations. After Marbury, he did not use judicial review to attack the Jeffersonians. Nor in Gibbons did he deny the states' power to regulate commerce. He did not, in other words, ignore the kind of prudent calculations that his confident tone would appear to override. This broad streak of prudence perhaps helps to explain his extraordinarily long record of influence. At the beginning, his colleagues on the Court were fellow Federalists and, to be blunt, mostly mediocrities. Justice Johnson, for instance, complained to Jefferson that "Cushing was incompetent," Chase "could not be made to think or write," Patterson was "a slow man," and "the other two judges . . . are commonly estimated as one judge." ${ }^{173}$ Marshall's

169 Plato's Meno, 77b2-78b6 (R.S. Buck trans. 1961).

170 Niccolo Machiavelli, The Prince chs. 16, 17 (Rufus Goodwin trans. 2003).

171 Thomas Hobbes, The Elements of Law, Natural and Politic ch. 7 (J.C.A. Gaskin ed., 2008).

172 G. Edward White, The Marshall Court and Cultural Change 181 (1988).

173 Donald G. Morgan, Mr. Justice Johnson and the Constitution, 57 Harv. L. Rev. 328 
opportunity to impose his will through the powers of his office (e.g., assigning opinions) and the force of his personality (e.g., the discussions with his colleagues) would be obvious. By 1810, however, the Federalists were no longer a majority on the Court. Yet when Jeffersonians added powerful personalities to the Court, like Johnson and Story, Marshall turned them into allies. Meanwhile, passive justices, like Duvall or Todd (neither of whom produced an average of a single opinion per year) offered little resistance.

During his tenure, Marshall wrote 547 opinions for the Court, nearly half of the 1106 cases it decided, and many of these opinions were of considerable significance. At the same time, he wrote only eight dissents. On the surface, this would seem to point to near dictatorial dominance. But there is less here than meets the eye, for Marshall admitted that rather than dissent, he ordinarily chose to "acquiesce silently in [the Court's] opinion." ${ }^{174}$ Indeed, his colleague, Justice Johnson, reported that Marshall sometimes wrote and delivered the opinion for the Court, even when it was "contrary to his own judgment and vote." ${ }^{175}$ Opinions in his later years took all of three weeks to produce, perhaps reflecting the need for more consultation with his colleagues. By his last decade on the bench, he had become more a consensus builder. The typical vote, as always, was unanimous, but he frequently was forced to compromise.

All this suggests that Marshall to an unusual degree was able to combine two kinds of leadership, task and social, ${ }^{176}$ where the task leader focuses on completing the job effectively and efficiently and the social leader is concerned with creating a congenial environment that conduces to cooperation. Typically, leaders may be placed solidly in one camp or another, like the Intel chief executive officer, Andy Grove, an immensely gifted task leader, but a social leader whose approach, in the words of a colleague, "was to hit you over the head with a two-by-four." 177 As time passed and the composition of the Court evolved, Marshall may have adjusted by emphasizing his always potent social leader skills.

Marshall's prudent, calculating leadership co-exists uneasily with his barreling forcefulness and its hint of uninhibited delight in verbal combat. It contrasts, too, with his universal reputation for amiability, for his judicial language was not at all inoffensive or soft spoken, but instead aggressive and unyielding, at times even pugnacious and partisan, as in his attacks on Jefferson's administration in Marbury or on Maryland in McCulloch. Yet on the other hand, the style comported perfectly with one of whom a contemporary remarked, "In his whole appearance and demeanor, dress, attitudes, gesture, sitting, standing, or walking [Marshall] is as far removed from the idealized graces of Lord Chesterfield, as any other gentleman on earth." 178 In rejecting highfalutin' display, he naturally also eschewed metaphors and other nonliteral devices, then so fashionable, that can seduce us into seeing with clarity something that is not there.

174 Bank of the United States v. Dandridge, 12 Wheaton 64 (1827).

175 Supra note 173, at 333.

176 Robert F. Bales, Task Roles and Social Roles in Problem-Solving Groups, in ReAdings IN Social Psychology 437, 441 (Eleanor E. Maccoby et al. eds., 3d ed. 1958).

177 Jonathan Kandall, Andrew Grove Dies at 79; Intel Chief Spurred Semiconductor Revolution. N.Y. TIMEs, Mar.21, 2016.

178 William Wirt, The Writings of a British Spy 110 (1836). 
There was, too, a certain ambivalence about Marshall's views of the role of the people in political affairs. He celebrated the Constitution as representing the deliberate voice of the people - and hence, superior to conflicting statutes from Congress or states. And yet, like many other leaders of the time, he distrusted ordinary citizens en mass, thinking them "selfish, violent, capricious, vindictive, and dangerous," 179 and refusing to retire and present the spokesman for the common man, Andrew Jackson, the opportunity to name his successor.

Perhaps because he was unassuming, "a genuinely modest man," 180 who did not even think to preserve his personal papers for posterity, Marshall's writing was not personal, like Justice Blackmun, with his anguish for an abused plaintiff ${ }^{181}$ or his passionate opposition to the death penalty. ${ }^{182}$ On the contrary. Marshall's language is formal, even dramatic, and rarely acknowledges that the decision could be different from what it is. His is not the tone of Holmes with his epigrams, Frankfurter with his professorial admonitions or Scalia with his paroxysms of indignation. Instead, the impression left with the reader is irresistible power. It is a lumbering locomotive, and our choice is to climb aboard or get run over, hardly the prose of a genuinely modest man.

Which raises the question of how modest he truly was. Marshall, as Story put it, was not lacking in a sense of self worth. "No one," he said, "ever possessed a more entire sense of his extraordinary talents." 183 Where certain other justices like, say, Frankfurter, habitually explained how complicated cases were, Marshall, like, say, Black, was a simplifier, who "distilled an argument down to its essence."184 This may have resulted from his distaste for formal legal research and consequently heavy reliance on oral argument. He was a quick study and he knew it. Precedents, apart from his own decisions, ${ }^{185}$ did not interest him much. In any event, such a sustained commitment to simplification bespeaks considerable self confidence. He never doubted his ability to strip away nonessentials and get to the nub of the matter, though much of what he discarded would have seemed relevant to many others. Their views evidently did not bother him.

From the outset, Marshall was a result-oriented judge. If America were to fulfill its great promise, he believed, it must have a strong national government, strong property rights, and a strong Supreme Court to defend them. All this came to him not from abstract speculation but from practical experience. In this regard, his days as a soldier in the War for Independence carried considerable weight, for he saw at Valley Forge and elsewhere how the states could not be trusted to meet their obligations and how only a strong national government could protect the fledgling nation from internal divisions and rapacious imperial powers. Courts, he hoped, could impose a rule of law and safeguard the society from self interested politics. "The judges of the Supreme Court," he wrote, "separated from the people . . . are viewed with respect, unmingled with affection, or interest. They possess neither

79 Supra note 26, at I: 253.

180 Supra note 126, at 1467.

181 DeShaney v. Winnebago Cty. Dep’t. Soc. Services, 489 U.S. 189, 213 (1989).

182 Callins v. Collins, 510 U.S. 1141, 1145 (1994).

183 John M. Dillon, John Marshall, Complete Constitutional Decisions 363 (1903).

184 Leonard Baker, John Marshall, A Life in the Law 709 (1974).

185 See Brown v. Maryland, 12 Wheaton 419, 446, 449 (1827), which explicitly relied on Gibbons and McCulloch, respectively. 
power nor patronage." ${ }^{186}$ Hence, the contradiction so apparent two centuries later the figure who made America's independent appellate judiciary a reality was driven by his own deeply held political convictions - entirely escaped his notice. Perhaps this reflected the prevailing fiction that judges did not make law, but merely applied universal principles in particular cases. But the sharply enhanced role he seized for the Court, legal and political, evidently led his colleagues to take an increasing pride in the institution that, in turn, added to its prestige and authority. ${ }^{187}$ The results he sought invariably in his eyes coincided with the intentions of the Framers. He was, as Corwin said, "thoroughly persuaded that he knew [their] intentions ... and equally determined that their intentions should prevail." 188

As a young man, "Pope was the lad's especial textbook,"189 and The Essay of Man's preoccupation with universal laws governing humanity is evident in Marshall's opinions, which are strewn with such generalities. But the greatest influence may well have come from Blackstone, who was so widely read in the colonies that Burke thought nearly as many copies of his Commentaries were bought there as in England. ${ }^{190}$ Marshall's father had bought the Commentaries, and he "saw to it that his son read Blackstone as carefully as circumstances permitted." ${ }^{191}$ Later, his law notes, which he used to prepare for the bar, reveal Blackstone's continuing influence. ${ }^{192}$ Blackstone disdained philosophical speculation, preferring common sense, often expressed in maxims, and Marshall exhibits a weakness for maxims, too: "The power to tax involves the power to destroy," "A legislative act contrary to the Constitution is not law," "it is emphatically the province and duty of the judicial department to say what the law is," "Between a balanced republic and a democracy, the difference is like between order and chaos." As to the guides to common sense, Blackstone favored the common law or what he took to be the general approval of mankind. Natural law, human nature, the laws of England - all of these melted one into another. More generally, "Revolutionary era lawyers unreflectively conflated reason and custom." 193 For Marshall, too, practical concerns (sometimes disguised by sonorous references) carried the day, and maxims or the general approval of mankind clinched the argument. Natural law, by itself, seemed too amorphous and ambiguous to be able to justify the economic rights he considered central.

In this, Marshall's approach, in common with the general practice of the day, was foundational, in the sense of explaining political and legal arrangements in terms of givens. God, human nature, society - these imperishable, unalterable forces governed human affairs, and it would be folly to challenge them. The people, driven by their emotions, might fail to grasp this, but judges, working within a common law tradition, would naturally take the long view. The relentless

186 Gerald Gunther, John Marshall's Defense of McCulloch v. Maryland 78-79 (1969).

187 Arguably, the pride when applied to Dred Scott, Scott v. Sandford, 60 U.S. 393 (1857) became hubris, as a majority imagined that with their ruling they had saved the nation from a terrible civil war.

188 Supra note 163 , at 122.

189 Id. at 27.

190 Edmund Burke, SpeEches 87 (1853).

191 Supra note 29, at I:56 (1929).

192 William F. Swindler, John Marshall's Preparation for the Bar-Some Observations on His Law Notes, 11 Am. J. Leg. Hist. 207 (1967).

193 James Q. Whitman, Why Did the Revolutionary Lawyers Confuse Custom and Reason? 58 U. ChI. L. Rev. 1321, 1323 (1991). 
interrogation of conventional wisdom, taken for granted today, was in his day never considered.

Speaking on the hundredth anniversary of Marshall's taking the seat as chief justice, Holmes was characteristically ungenerous. "If I were to think of John Marshall simply by number and measure in the abstract, I might hesitate in my superlatives ... A great man represents a great ganglion in the nerves of society, or, to vary the figure, a strategic point in the campaign of history, and part of his greatness consists in his being there." 194 Marshall was certainly there, and much of the credit for the power and stature of the Supreme Court reflects his efforts. On the other hand, John Jay and Oliver Ellsworth, who preceded him as chief, were also there, and they left the Court inconsequential. As Chief Justice Hughes observed, "Marshall's preeminence was due to the fact that he was John Marshall."195 Opportunity knocked, as the cliché goes, but only Marshall had the vision and ability to open the door and speak with his powerfully distinctive voice.

194 Oliver Wendell Holmes, Speeches (1913).

195 Supra note 26, at 1 (1966). 